\title{
Compulsory Citizenship Behaviour among Academic Staff of Private Higher Education Institutions in Melaka, Malaysia
}

\author{
Ng Chee Yieng, Goh Mei Ling, Wendy Teoh Ming Yen
}

\begin{abstract}
Compulsory citizenship behaviour (CCB) refers to employees who perform extra-role behaviour against their will. The study is among one of a handful on compulsory citizenship behaviour if compared with organisational citizenship behaviour $(O C B)$, which are directed toward individuals (OCBI) and an organisation (OCBO) as a whole. Thus, this study mainly focuses examining the effect of intention to leave, job stress, sucker effect, burnout, organisational politics, negligent behaviour, and conflict between colleagues on compulsory citizenship behaviour. A total of 100 academic staff from private higher education institutions in Melaka participated in this study. Self-administered questionnaires were used for data collection and SmartPLS was employed to perform the analysis. The findings of this study reveal that negligent behaviour and organisational politics have a significant direct relationship with compulsory citizenship behaviour. This study not only has noteworthy contributions on enriching the available literature on compulsory citizenship behaviour, but also provides some important insights to employers in private higher education institutions in relation to their human capital management, which focuses on compulsory citizenship behaviour.
\end{abstract}

Index Terms: Compulsory Citizenship Behaviour; Organisational Citizenship Behaviour; Academic Staff.

\section{INTRODUCTION}

Organisations expect their employees to perform extra-role or organisational citizenship behaviour that is not stated in their job description (Zhao, Peng, \& Chen, 2014). Employees may accept the organisational citizenship behaviour in order to prepare themselves for a better position and remuneration in future accomplishments (Vigoda-Godat, 2006). Organisational citizenship behaviour can be defined as "individual behaviour that is discretionary, not directly or explicitly recognised by the formal reward system, and that in the aggregate promotes the effective functioning of the organisation" (Organ, 1988, p. 4). In other words, organisational citizenship behaviour is also called "good soldier syndrome" (Organ, 1988). The good soldier syndrome can be described as workers who willingly perform extra-role behaviours that are above and beyond their job tasks in order to increase the effectiveness and efficiency of

Revised Manuscript Received on October 25, 2019

Ng Chee Yieng, Putra International College.

Goh Mei Ling, Putra International College, Faculty of Business, Multimedia University.mlgoh@mmu.edu.my

Wendy Teoh Ming Yen, Putra International College, Faculty of Business, Multimedia University. the organisation (Vigoda-Godat, 2006). Individuals who tend to engage actively in organisational citizenship behaviour can be labelled as "good citizens" (Methot, Lepak, Shipp, \& Boswell, 2017). Organisational citizenship behaviour is presented with positive behaviour and tends to be voluntary. In contrast, compulsory citizenship behaviour presents when individuals are forced to perform extra-role activities involuntarily to engage in organisational citizenship behaviour (Ahmadian, Sesen, \& Soran, 2017).

Most studies on this topic have concentrated on the subject of organisational citizenship behaviour toward individuals (OCBI) and the organisation (OCBO). Only a handful of applied research studies have studied compulsory citizenship behaviour in global literature, such as China (Zhao et al., 2014; Zhao, Peng, Han, Sheard, \& Hudson, 2013), Israel (Vigoda-Gadot, 2007), and Turkey (Ahmadian et al., 2017). Vigoda-Gadot (2007) was the first researcher who studied compulsory citizenship behaviour and revealed the positive relationship between compulsory citizenship behaviour and the intention to leave, job stress, organisational politics, burnout, and negligent behaviour among Israeli teachers. Meanwhile, the recent study by Ahmadian et al. (2017) studying burnout, intention to leave, sucker effect, job stress, and conflict between colleagues found positive impacts on compulsory citizenship behaviour.

No empirical research on compulsory citizenship behaviour has focused on Malaysia, however. Our knowledge bank on compulsory citizenship behaviour has increased, but has yet to yield enough for global literature, especially in the Malaysian context. Thus, this research aims to study the relationship between compulsory citizenship behaviour and the variables from the studies by both Ahmadian et al. (2017) and Vigoda-Gadot (2007). More importantly, this study has attempted to focus on academic staff in private higher education institutions in Melaka, a state in Malaysia.

\section{Literature REVIEW}

\section{A. Compulsory Citizenship Behaviour (CCB)}

Compulsory citizenship behaviour is the behaviour that describes employees involuntarily engaging in extra-role or organisational citizenship behaviour (Vigoda-Gadot, 2007). Compulsory citizenship behaviour usually occurs when employees begin to feel pressure or stress to execute extra-role activities. Apart from that,

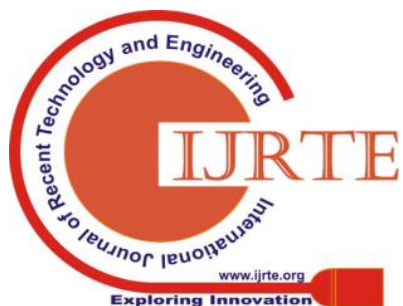


employees are expected to work more hours and beyond their formal job scope, without any formal rewards (Vigoda-Gadot, 2007). The findings in Vigoda-Gadot's study reported that most Israeli teachers commonly carried extra-role tasks in their working environment. More specifically, compulsory citizenship behaviour happens when a manager or supervisor who excessively abuses their power demands that their employees perform extra activities against their will (Vigoda-Godat, 2006). Ahmadian et al. (2017) opined that compulsory citizenship behaviour can lead to some negative effects on both the individual and the organisation. These impacts include increasing employees' intention to quit, job stress, burnout, negligent behaviour, sucker effect, organisational politics, and conflict between colleagues.

\section{B. Intention to leave}

Intention to leave refers to an employee who intends to discontinue his or her service with an organisation (Saraih et al., 2017). Though the intention to leave can be reflected only as an employee's desire to quit the organisation, the employee does not actually resign (Kehoe \& Wright, 2013). Vigoda-Gadot (2007) revealed that the intention to leave has a significant influence on compulsory citizenship behaviour. Israeli teachers in his sample tended to quit the organisation when they started feeling high pressure with extra-role tasks from supervisors.

\section{Job stress}

When employees perceive an excessive workload over their capabilities it can be defined as job stress (Tziner \& Sharoni, 2014). Job stress was found to have a positively significant influence on compulsory citizenship behaviour (Zhan et al., 2017). According to Zhan et al. (2017), job stress was determined to have a mediating effect between the organisational ethical climate and compulsory citizenship behaviour among employees in Chinese organisations. A similar result was also found by Ahmadian et al. (2017), who analysed the compulsory citizenship behaviour of accommodation business workers in Turkey. As the results in his study show, the workers were more stressed when their supervisors' supervision was related to compulsory citizenship behaviour.

\section{Burnout}

According to Maslach, Jackson, and Leiter (1997), burnout is an employee's negative reaction that leads to his or her emotional and physical exhaustion, depersonalisation, and lower individual achievement. A common consequence of burnout is the reduction of an employee's job performance, which can then cause the withdrawal of organisational citizenship behaviour (Cohen \& Abedallah, 2015). Vigoda-Godat (2006) demonstrated that burnout extension was the result of high levels of compulsory citizenship behaviour. Moreover, Ahmadian et al. (2017) showed the same results as past studies, with a positive relationship between compulsory citizenship behaviour and burnout.

\section{E. Negligent behavior}

Negligent behaviour is defined and explained as an individual purposely reducing the effort put into his or her job (Vigoda-Gadot, 2007). It often causes the job situation to be more troublesome. As indicated in his study, negligent behaviour was found to have a positive impact on compulsory citizenship behaviour. Vigoda-Godat (2006) also suggested that in-role or extra-role activities were crucial elements of an employee's behaviour in his or her workplace. The workers' perceptions and behaviours will vary because they define in-role as freedom to help colleagues, while extra-role includes activities that require some formal reward from the organisation.

\section{F. Sucker effect}

Sucker effect has been defined as the reaction of an employee to the social loafing actions of his or her colleagues (Ahmadian et al., 2017). An employee tends to exert less effort if his or her co-worker applies social loafing in the workplace (Şeşen, Soran, \& Caymaz, 2014). In fact, social loafing behaviour-caused compulsory citizenship behaviour occurred in the organisation (Ahmadian et al., 2017). For example, employees put in as little effort as they were able to because their colleagues were not willing to contribute their maximum effort.

\section{G. Organisational politics}

Organisational politics is defined as an individual's actions that focus on self-interest without considering the welfare of others or his/her own organisation (Kacmar \& Baron, 1999). In the political environment, employees are assumed to fulfill a greater job scope, especially the extra-role, without formal reward or recognition. However, employees may tend to feel pressure to practice extra-role in a high-level political workplace and turn out voluntary behaviour to become compulsory citizenship behaviour (Alkan, 2015). Ahmadian et al. (2017) found that organisational politics make a positive contribution toward compulsory citizenship behaviour. This finding is also in accordance with findings by Alkan (2015).

\section{H. Conflict between colleagues}

The conflict that happens in the workplace involving two or more employees can be explained as conflict between colleagues (Beheshtifar, 2013). It is commonly called an interpersonal conflict. Ahmadian et al. (2017) found that conflict between colleagues was positively correlated with compulsory citizenship behaviour. For example, "my colleagues often shout at me and rude to me" (Ahmadian et al., 2017).

Based on the above discussion, the following hypotheses have been developed, as presented in Figure 1.

H1: Intention to leave has a positive impact on compulsory citizenship behaviour.

H2: Job stress has a positive impact on compulsory citizenship behaviour.

H3: Sucker effect has a positive impact on compulsory citizenship

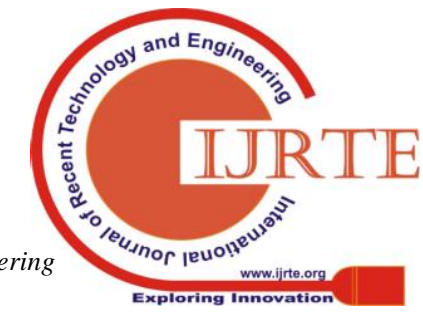


behaviour.

H4: Burnout has a positive impact on compulsory citizenship behaviour.

H5: Organisational politics have a positive impact on compulsory citizenship behaviour.

H6: Negligent behaviour has a positive impact on compulsory citizenship behaviour

H7: Conflict between colleagues has a positive impact on compulsory citizenship behaviour.

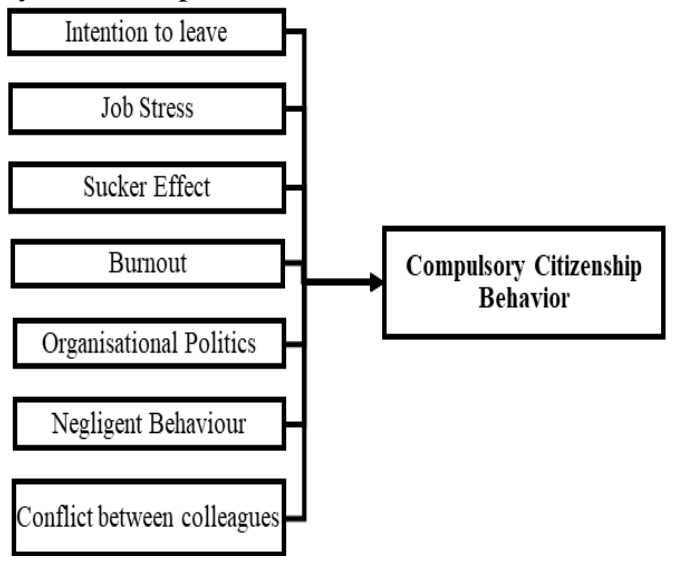

Fig 1. Hypotheses Development on Compulsory Citizenship Behaviour among Academic Staff of Private Higher Education Institutions in Melaka, Malaysia

\section{Methodology/Materials}

A total of 100 academic staff from private higher education institutions in Melaka participated in this study. Convenience sampling was used for data collection. A self-administrated questionnaire was designed and distributed via email (Google form link) and face-to-face samples were taken on topics ranging from the demographic background of respondents to all the variables studied. Compulsory citizenship behaviour (five items), intention to leave (four items), job stress (four items), sucker effect (five items), burnout (six items), organisational politics (seven items), negligent behaviour (four items), and conflict between colleagues (four items) were adapted from Ahmadian et al. (2017) and Vigoda-Gadot (2007) using a five-point Likert scale (1=Strongly Disagree to 5=Strongly Agree). Structural Equation Modelling (SEM) was performed using SmartPLS version 3 to study the relationships between all the constructs and compulsory citizenship behaviour. Convergent validity and discriminant validity were also used to assess the collected data.

\section{RESUlts AND FINDINGS}

In this study, a majority of the respondents were female (62\%), while the highest age group was 30-34 (30\%), followed by 35-39 (29\%). More than half of the respondents had obtained a master's degree (64\%), 27\% had earned doctoral degrees, followed by $8 \%$ had had received a bachelor's degree, and only $1 \%$ had a different educational background. Among those who filled out the questionnaire, $64 \%$ were married. About two thirds (72\%) of the respondents were holding lecturer positions, followed by the role of senior lecturer (22\%), professor $(5 \%)$, and associate professor (1\%). A majority of them had more than 15 years' experience in teaching (22\%) and $7 \%$ had taught for more than 20 years.

\section{A. Measurement Model}

The convergent validity of the model can be verified by factor loadings, average variance extracted (AVE), and construct reliability $(\mathrm{CR})$ with a minimum value of $0.7,0.5$, and 0.7 , respectively, as suggested by Hair et al. (2017). Item OP2 with factor loading less than 0.5 was deleted. As illustrated in Table 1, all the factor loadings were above 0.7 , AVE was greater than 0.5, and CR exceed 0.7. Convergent validity is therefore adequate.

Two assessment criteria were used to examine the discriminant validity: (1) Fornell and Larcker (1981) criterion, which compared the correlations between the constructs with the square root of the AVE in the verification; and (2) Heterotrait-monotrait (HTMT) criterion (Henseler, Ringle, \& Sarstedt, 2015) which compared the HTMT values obtained with the threshold of HTMT H5 $_{.85}$ (Kline, 2011) or HTMT .90 (Gold, Malthora, \& Segars, 2001). Table 2 shows that all square roots of AVE (in diagonal) are greater than the correlation coefficient between all the constructs, and all HTMT values obtained as presented in Table 3 also achieved HTMT. .85 and HTMT.90. This means that discriminant validity using both criteria is satisfactory. TABLE 1: MEASUREMENT MODEL

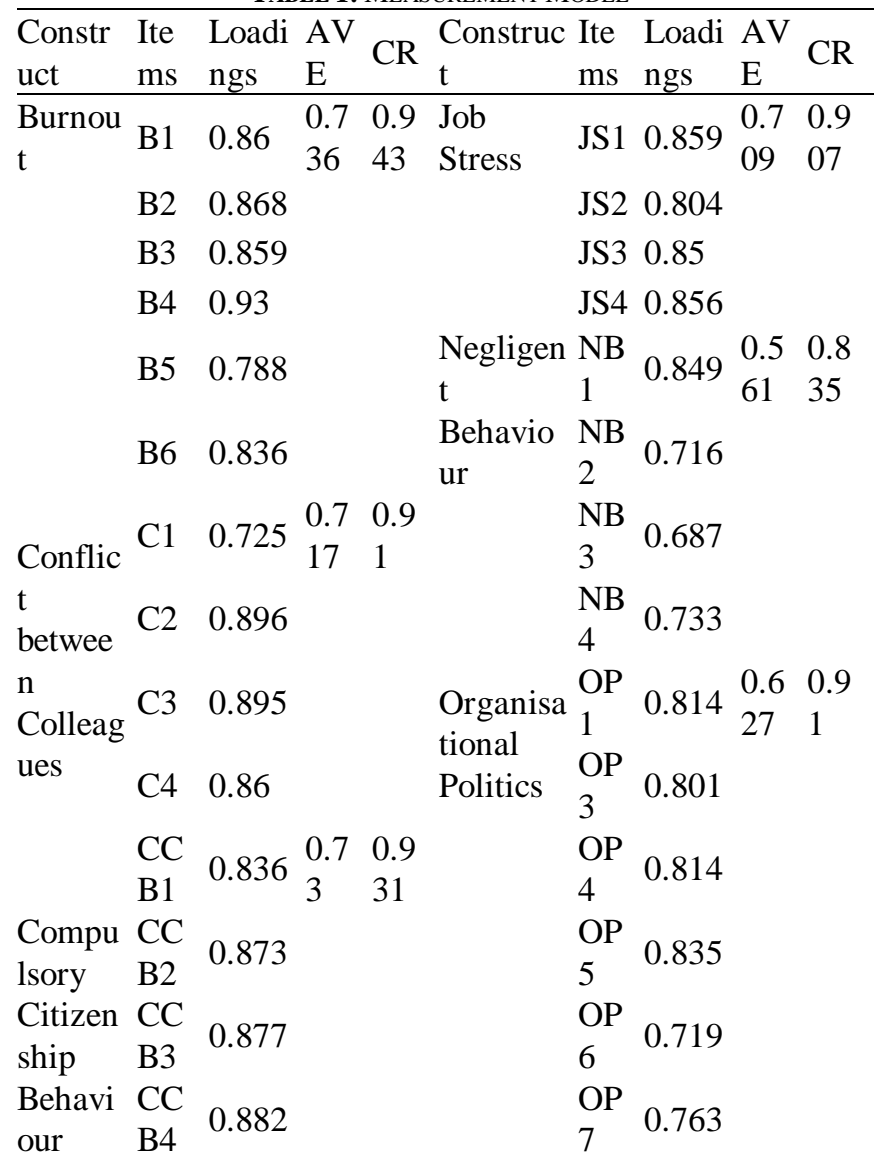

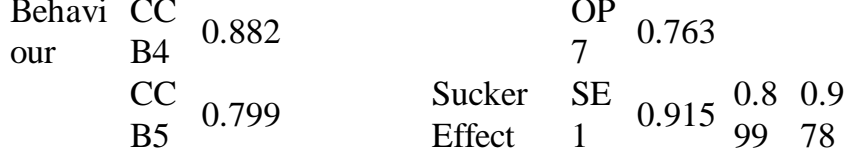

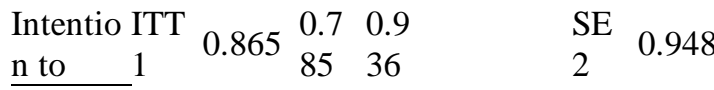




\begin{tabular}{|c|c|c|c|c|c|c|c|c|c|}
\hline Leave & $\begin{array}{l}\text { ITT } \\
2 \\
\text { ITT } \\
3 \\
\text { ITT } \\
4\end{array}$ & & & & $\begin{array}{l}\mathrm{S} \\
3 \\
\mathrm{~S} \\
4 \\
\mathrm{~S} \\
5\end{array}$ & $\begin{array}{ll}\mathrm{E} & 0 \\
& 0 \\
\mathrm{E} & 0 \\
& 0 \\
& 0\end{array}$ & .963 & & \\
\hline ABLE & 2: DISCR & & U & $\mathrm{GFO}$ & NELL & -LAR & CKE & CRITE & RION \\
\hline & & & & 3 & 4 & 5 & 6 & 7 & 8 \\
\hline 1. Burr & out & & & & & & & & \\
\hline 2. Com & pulsory & & .8 & & & & & & \\
\hline Citizen & ship B & & 54 & & & & & & \\
\hline 3. Con & lict bet & & .3 & 0.8 & & & & & \\
\hline Collea & ues & & 56 & 47 & & & & & \\
\hline 4. Inter & tion to & & 0.5 & $\begin{array}{l}0.3 \\
05\end{array}$ & $\begin{array}{l}0.8 \\
86\end{array}$ & & & & \\
\hline 5. Job & tress & & $\begin{array}{l}.4 \\
65\end{array}$ & $\begin{array}{l}0.2 \\
42\end{array}$ & $\begin{array}{l}0.5 \\
74\end{array}$ & $\begin{array}{l}0.8 \\
42\end{array}$ & & & \\
\hline 6. Neg & igent B & & 56 & $\begin{array}{l}0.2 \\
91\end{array}$ & $\begin{array}{l}0.5 \\
86\end{array}$ & $\begin{array}{l}0.6 \\
04\end{array}$ & $\begin{array}{l}0.7 \\
49\end{array}$ & & \\
\hline 7. Org & nisatio & & 0.6 & 0.4 & 0.4 & 0.5 & 0.6 & 0.7 & \\
\hline Politic & & & 19 & 61 & 86 & 45 & 49 & 92 & \\
\hline 8. Such & er Effe & & $\begin{array}{l}.4 \\
39\end{array}$ & $\begin{array}{l}0.4 \\
08\end{array}$ & $\begin{array}{l}0.4 \\
8\end{array}$ & $\begin{array}{l}0.5 \\
25\end{array}$ & $\begin{array}{l}0.7 \\
14\end{array}$ & $\begin{array}{l}0.5 \\
61\end{array}$ & $\begin{array}{l}0.9 \\
48\end{array}$ \\
\hline
\end{tabular}

Notes: Values on the diagonal (bolded) represent square root of the AVE while the off-diagonals represent correlations

TABLE 3: DISCRIMINANT VALIDITY USING HTMT CRITERION

\begin{tabular}{lllllllll}
\hline & 1 & 2 & 3 & 4 & 5 & 6 & 7 & 8 \\
\hline 1. Burnout & & & & & & & & \\
2. Compulsory & 0.5 & & & & & & & \\
Citizenship Behaviour & 43 & & & & & & & \\
3. Conflict between & 0.2 & 0.4 & & & & & & \\
Colleagues & 6 & 08 & & & & & & \\
4. Intention to Leave & 0.5 & 0.5 & 0.3 & & & & \\
& 48 & 47 & 46 & & & & \\
5. Job Stress & 0.8 & 0.5 & 0.2 & 0.6 & & & \\
& 38 & 15 & 84 & 45 & & & \\
6. Negligent Behaviour & 0.7 & 0.7 & 0.3 & 0.6 & 0.7 & & \\
7. Organisational & 11 & 69 & 33 & 82 & 29 & & \\
Politics & 0.6 & 0.6 & 0.5 & 0.5 & 0.6 & 0.7 & \\
& 49 & 82 & 31 & 32 & 28 & 59 & \\
8. Sucker Effect & 0.5 & 0.5 & 0.4 & 0.5 & 0.5 & 0.8 & 0.6 \\
& 85 & 12 & 45 & 07 & 77 & 16 & 07 \\
\hline
\end{tabular}

\section{B. Structural Model}

Seven hypotheses were developed and tested in the structural model. The findings are presented in Table 4. The $\mathrm{R}$-squared value for compulsory citizenship behaviour was 0.521 , which can be deemed as moderate as discussed by Henseler, Ringle, and Sinkovics (2009). This implies that $52.1 \%$ of the total variation in compulsory citizenship behaviour was explained by all exploratory variables. Negligent behaviour $(\beta=0.432)$ and organisational politics $(\beta$ value $=0.249$ ) were found to have a positive impact on compulsory citizenship behaviour. In contrast, burnout $(\beta=0.104)$, conflict $(\beta=0.119)$, intention to leave $(\beta=0.2111)$, job stress $(\beta=-0.054)$, and sucker effect $(\beta=-0.09)$ did not explain compulsory citizenship behaviour as, their t-values did not exceed the critical value of 1.6449 (Alpha level of
$5 \%)$.

Effect size (f-squared) is important in quantifying the differences between two groups by examining the relationship's strengths on a numeric scale (Cohen, 1998; Wong, 2016). The effect size obtained for all variables was less than 0.02, indicating that a small effect occurred in producing the R-squared for compulsory citizenship behaviour (Cohen, 1998). A blindfolding procedure was conducted to measure the criterion for the cross-validated predictive relevance. As Q-squared is greater than zero (0.324), it shows that the model has predictive relevancy (Akter, Ambra, \& Ray, 2011). All of the independent variables' Variance Inflation Factor (VIF) values were also below the threshold of 5, indicating that collinearity is not a concern (Hair et al., 2017). Overall, two out of seven variables, i.e., negligent behaviour and organisational politics, were supported, while others were rejected in this study.

TABle 4: Results OF STRUCTURAL MOdel

\begin{tabular}{|c|c|c|c|c|c|c|c|c|c|}
\hline $\begin{array}{l}\text { Hypo } \\
\text { thesis }\end{array}$ & $\begin{array}{l}\text { Relation } \\
\text { ship }\end{array}$ & $\begin{array}{l}\text { Std. } \\
\text { Beta }\end{array}$ & $\begin{array}{l}\text { Std. } \\
\text { Err } \\
\text { or }\end{array}$ & $\begin{array}{l}\text { t-val } \\
\text { ue }\end{array}$ & $\begin{array}{l}\text { Decisi } \\
\text { on }\end{array}$ & $\mathrm{R} 2$ & Q2 & f2 & VIF \\
\hline H1 & $\begin{array}{l}\text { Burnout } \\
->\mathrm{CCB}\end{array}$ & 0.104 & $\begin{array}{l}0.1 \\
3\end{array}$ & $\begin{array}{l}0.79 \\
9\end{array}$ & $\begin{array}{l}\text { Not } \\
\text { Suppo } \\
\text { rted }\end{array}$ & $\begin{array}{l}0.5 \\
21\end{array}$ & $\begin{array}{l}0.3 \\
24\end{array}$ & $\begin{array}{l}0.00 \\
8\end{array}$ & $\begin{array}{l}2.6 \\
63\end{array}$ \\
\hline $\mathrm{H} 2$ & $\begin{array}{l}\text { Conflict } \\
->\mathrm{CCB}\end{array}$ & 0.119 & $\begin{array}{l}0.0 \\
93\end{array}$ & 1.27 & $\begin{array}{l}\text { Not } \\
\text { Suppo } \\
\text { rted }\end{array}$ & & & $\begin{array}{l}0.02 \\
1\end{array}$ & $\begin{array}{l}1.3 \\
96\end{array}$ \\
\hline H3 & $\begin{array}{l}\text { Intention } \\
\text { to Leave } \\
->\mathrm{CCB}\end{array}$ & 0.111 & $\begin{array}{l}0.1 \\
16\end{array}$ & $\begin{array}{l}0.95 \\
2\end{array}$ & $\begin{array}{l}\text { Not } \\
\text { Suppo } \\
\text { rted }\end{array}$ & & & $\begin{array}{l}0.01 \\
4\end{array}$ & $\begin{array}{l}1.7 \\
70\end{array}$ \\
\hline H4 & $\begin{array}{l}\text { Job } \\
\text { Stress -> } \\
\text { CCB }\end{array}$ & $\begin{array}{l}-0.05 \\
4\end{array}$ & $\begin{array}{l}0.1 \\
64\end{array}$ & $\begin{array}{l}0.32 \\
8\end{array}$ & $\begin{array}{l}\text { Not } \\
\text { Suppo } \\
\text { rted }\end{array}$ & & & $\begin{array}{l}0.00 \\
2\end{array}$ & $\begin{array}{l}2.6 \\
49\end{array}$ \\
\hline H5 & $\begin{array}{l}\text { Negligen } \\
\mathrm{t} \\
\text { Behavio } \\
\text { ur } \\
->\mathrm{CCB}\end{array}$ & 0.432 & $\begin{array}{l}0.1 \\
2\end{array}$ & $\begin{array}{l}3.60 \\
2 * *\end{array}$ & $\begin{array}{l}\text { Suppo } \\
\text { rted }\end{array}$ & & & $\begin{array}{l}0.13 \\
2\end{array}$ & $\begin{array}{l}2.9 \\
47\end{array}$ \\
\hline H6 & $\begin{array}{l}\text { Organisa } \\
\text { tional } \\
\text { Politics } \\
->\mathrm{CCB}\end{array}$ & 0.249 & $\begin{array}{l}0.1 \\
24\end{array}$ & $\begin{array}{l}2.00 \\
5^{*}\end{array}$ & $\begin{array}{l}\text { Suppo } \\
\text { rted }\end{array}$ & & & $\begin{array}{l}0.05 \\
8\end{array}$ & $\begin{array}{l}2.2 \\
44\end{array}$ \\
\hline H7 & $\begin{array}{l}\text { Sucker } \\
\text { Effect -> } \\
\text { CCB }\end{array}$ & -0.09 & $\begin{array}{l}0.1 \\
34\end{array}$ & $\begin{array}{l}0.67 \\
6\end{array}$ & $\begin{array}{l}\text { Not } \\
\text { Suppo } \\
\text { rted }\end{array}$ & & & $\begin{array}{l}0.00 \\
7\end{array}$ & $\begin{array}{l}2.3 \\
56\end{array}$ \\
\hline
\end{tabular}

Note: $* * p<0.01, * p<0.05$

\section{Discussion}

Intention to leave was found to be unrelated to compulsory citizenship behaviour in this study; hence, H1 was not supported. This result conflicts with prior studies confirming the positive correlation between intention to leave and compulsory citizenship behaviour (Ahmadian et al., 2017; Vigoda-Gadot, 2007). This could be explained by the fact that academic staff have not yet thought of quitting their current job. This could be due to the fact that there are limited job opportunities in Melaka, as there are few 
private universities and colleges compared with big cities like Kuala Lumpur.

Job stress also was not influenced by compulsory citizenship behaviour. Thus, $\mathrm{H} 2$ was not supported. This is contrary to the findings of some previous studies, which pointed out that job stress had a significant relationship with compulsory citizenship behaviour (Vigoda-Gadot, 2007; Zhan et al., 2017). This indicates that performing extra-role tasks has caused no job stress among the academic staff in Melaka's private institutions. The reason behind this is unclear. However, most respondents in this study had more than 15 years of teaching experience in higher education. Therefore, they may be able to work under stress.

This study has confirmed that sucker effect, burnout, and conflict have no influence on compulsory citizenship behaviour; H3, H4, and $\mathrm{H} 7$ are thus unsupported. These findings are not consistent with previous studies (Ahmadian et al., 2017; Vigoda-Gadot, 2007). A possible reason behind this is that academic staff in private higher institutions in Melaka are more willing to perform extra-role activities for the sake of potential future benefits and career development opportunities (Vigoda-Gadot, 2007). Therefore, these factors were not found to influence compulsory citizenship behaviour.

On the other hand, organisational politics were found to have a positive influence on compulsory citizenship behaviour; H5 was thus supported. This finding is in line with previous studies (Ahmadian et al., 2017; Vigoda-Gadot, 2007). The study by Alkan (2015) confirmed that organisational politics were positively correlated with compulsory citizenship behaviour. In other words, employees who were working in a political working environment tended to unwillingly handle extra-roles. The working environment, shaped by the management team and colleagues, has a direct influence on compulsory citizenship behaviour (Vigoda-Gadot, 2007).

This study also revealed that negligent behaviour has a positive influence on compulsory citizenship behaviour, thus supporting H6. This finding is consistent with Vigoda-Gadot (2007), who stated that negligent behaviour was an important factor in compulsory citizenship behaviour. This means that compulsory citizenship behaviour can occur when employees are passively involved in their job scope and even postpone important deadlines. (Ahmadian et al., 2017).

\section{Conclusion}

A majority of employers tend to expect their employees to play take on extra-role activities in an organisation with no formal reward or recognition; this is also known as organisational citizenship behaviour. Without a doubt, organisational citizenship behaviour is a positive behaviour and employees tend to do this work more willingly. Yet compulsory citizenship behaviour occurs when employees are forced to perform extra-role tasks. This study set out to examine the factors of compulsory citizenship behaviour. politics and negligent behaviour have a positive impact on compulsory citizenship behaviour. Yet intention to leave, job This study's findings have indicated that only organisational

stress, sucker effect, burnout, and conflict between colleagues had no significant influence on compulsory citizenship behaviour. It is therefore recommended that further studies investigate organisational politics and negligent behaviour.

Nevertheless, this study has made several noteworthy contributions. The findings of this study have enriched the available literature on compulsory citizenship behaviour which still remains a neglected topic, especially in Malaysia. Meanwhile, this study should also provide some useful information to employers in terms of compulsory citizenship behaviour, especially for private higher education institutions in relation to human capital management. For instance, employers should create a working environment with fewer politics among management and employees. Employers should also make sure that all job descriptions are clearly stated in employment agreements, especially with regard to extra-role tasks.

\section{REFERENCES}

[1] Ahmadian, S., Sesen, H., \& Soran, S. (2017). Expanding the boundaries of compulsory citizenship behavior: Its impact on some organizational outputs. Business and Economic Horizons, 13(1), 110-118.

[2] Akter, S., Ambra, J. D., \& Ray, P. (2011). An Evaluation of PLS Based Complex Models: The Roles of Power Analysis, Predictive Relevance and Gof Index. In Proceedings of the Seventeenth Americas Conference on Information Systems (AMCIS2011) (pp. 1-7).

[3] Alkan, S. E. (2015). A research about the relationship of psychological safety and organizational politics perception with compulsory citizenship behavior and the pressures behind compulsory citizenship behavior. Pressacademia, 2(2), 185-185.

[4] Beheshtifar, M. (2013). Interpersonal conflict: A substantial factor to organisational failure. International Journal of Academic Research in Business and Social Sciences, 3(5), 354-362.

[5] Cohen, A., \& Abedallah, M. (2015). The mediating role of burnout on the relationship of emotional intelligence and self-efficacy with OCB and performance. Management Research Review, 38(1), 2-28.

[6] Cohen, J. (1998). Statistical Power Analysis for the Behavioural Sciences (2nd ed.). Lawrence Erlbaum Associates.

[7] Fornell, C., \& Larcker, D. F. (1981). Evaluating structural equation models with unobservable variables and measurement error. Journal of Marketing Research, 18(1), 39-50.

[8] Gold, A. H., Malthora, A., \& Segars, A. H. (2001). Knowledge management: An organizational capabilities perspective. Journal of Management Information Systems, 18(1), 185-214.

[9] Henseler, J., Ringle, C. M., \& Sarstedt, M. (2015). A new criterion for assessing discriminant validity in variance-based structural equation modeling. Journal of the Academy of Marketing Science, 43(1), $115-135$.

[10] Henseler, J., Ringle, C. M., \& Sinkovics, R. R. (2009). The use of partial least squares path modeling in international marketing. Advances in International Marketing, 20(2009), 277-319.

[11] Joseph F. Hair, J., Hult, G. T. M., Ringle, C., \& Sarstedt, M. (2017). A Primer on Partial Least Squares Structural Equation Modeling (PLS-SEM) (2nd ed.). Sage Publications.

[12] Kacmar, K. M., \& Baron, R. A. (1999). Organizational politics: The state of the field, links to related processes, and an agenda for future research Research in Personnel and Human Resources Management, 17, 1-39.

[13] Kehoe, R. R., \& Wright, P. M. (2013). The impact of high-performance human resource practices on employees' attitudes and behaviors. Journal of Management, 39(2), 366-391.

[14] Kline, R. B. (2011). Principles and practice of structural equation modeling. The Guilford Press.

[15] Maslach, C., Jackson, S., \& Leiter, M. P. (1997). The Maslach Burnout Inventory Manual. Evaluating Stress: A Book of Resources, (3) 191-218.

[16] Methot, J. R., Lepak, D., Shipp, A. J., \& Boswell, W. R. (2017). Good citizen interrupted: Calibrating a temporal theory of citizenship behavior. Academy of Management Review, 42(1), 10-31

[17] Organ, D. W. (1988). Organizational citizenship behavior: The good soldier syndrome. Lexington Books.

[18] Saraih, U. N., Aris, A. Z. Z., Karim, K. M., Samah, I. H. A., Sa'aban, S., \& Abdul Mutalib, S. (2017). 
Relationships between organizational commitment, OCB , organizational justice and turnover intention: evidence from educational institution in Malaysia. Review of Integrative Business and Economics Research, 6(2), 64-77.

[19] Şeşen, H., Soran, S., \& Caymaz, E. (2014). Dark side of organizational citizenship behavior (OCB): Testing a model between OCB, social loafing and organizational commitment. International Journal of Business and Social Science, 5(5), 125-135.

[20] Tziner, A., \& Sharoni, G. (2014). Organizational citizenship behavior, organizational justice, job stress, and workfamily conflict: Examination of their interrelationships with respondents from a non-Western culture. Journal of Work and Organizational Psychology, 30(1), 35-42.

[21] Vigoda-Gadot, E. (2007). Redrawing the boundaries of OCB? An empirical examination of compulsory extra-role behavior in the workplace. Journal of Business and Psychology, 21(3), 377-405.

[22] Vigoda-Godat, E. (2006). Compulsory citizenship behaviour: Theorizing some dark sides of the good soldier syndrome in organisations. Journal for the Theory of Social Behaviour, 36(18291-8308).

[23] Wong, K. K.-K. (2016). Mediation analysis, categorical moderation analysis, and higher-order constructs modeling in partial least squares structural equation modeling (PLS-SEM): A B2B example using SmartPLS. The Marketing Bulletin, 26, 1-22.

[24] Zhan, H., Hsieh, E., Wu, W., Lifang Peng, Xiong, Y., \& Yue "Jeff' Zhang. (2017). Research on the relationship between organizational ethical climate and compulsory citizenship behavior: mediated by job stress (pp. 1-6).

[25] Zhao, H., Peng, Z., \& Chen, H.-K. (2014). Compulsory citizenship behavior and organizational citizenship behavior: the role of organizational identification and perceived interactional justice. The Journal of Psychology, 148(2), 177-196.

[26] Zhao, H., Peng, Z., Han, Y., Sheard, G., \& Hudson, A. (2013). Psychological mechanism linking abusive supervision and compulsory citizenship behavior: A moderated mediation study. Journal of Psychology: Interdisciplinary and Applied, 147(2), 177-195. 